\title{
SOME CONSERVATIVE VIEWS UPON THE JUDI- CIARY AND JUDICIAL RECALL
}

The New York County Lawyers' Association recently appointed a Special Committee to investigate the causes of discontent with our judicial system and the manner in which justice is administered, and to recommend the abatement of evils, if any, and the correction of weaknesses, if any.

As a member of that Committee I concurred in its report, the substance of which was in part that a large part of the recent agitation is due to an endeavor, in spite of conflicting views, to settle the boundary between the public interest under the police power and the individual right to due process of law; that the doctrine of judicial recall appears largely to have spent its force; that the doctrine of the popular recall of judicial decisions is not rational and in practice would disappoint even its advocates; that both of said projects of recall menace judicial integrity as well as judicial independence; that the power of the Courts to pass upon the constitutionality of legislation has been widely recognized since the very foundation of our Government, both State and Federal, and its denunciation as a usurpation is a fallacy; and that the power should exist to prevent the Legislature from being the ultimate arbiter of the extent of its own powers.

The Committee recommended that judges be compelled (doubtless by the force of public opinion) to recognize that no law should be held unconstitutional unless it clearly transcends the legislative power; that the Federal Supreme Court be authorized to review State judgments; holding that State laws violate the Federal Constitution; that when a State Statute is assailed in the Courts, its Áttorney General should have an opportunity to be heard; that the freest criticism of the Bench and its decisions be encouraged; that impeachment and removal be made a ready remedy; and that more care be observed by Legislatures in the form of bills.

But the consideration of the subject of the report necessary to an adequate judgment provoked upon my part the following additional reflections concerning the much-discussed question of the recall of the judiciary and the grounds of the agitation, 
THE JUDICIAL POWER AND DUTY TO REGARD THE FEDERAL CONSTITUTION AS THE SUPREME LAW OF THE LAND.

The greatest part of the recent agitation has arisen from the exercise of this power, and many violent, ill-founded and ill-considered views have been expressed condemning it as a usurpation.

I am such a firm believer in the wisdom of our institutions as designed by the framers of the Federal Constitution that $I$ am unwilling and unable to concede to those who would modify them as much of an excuse as many persons appear to concede that they have. As for the contention that the judiciary has usurped any function in declaring legislation unconstitutional, appeal should not only be made to precedent and established usage, but to the logic of a fundamental supreme law. The conclusion seems to me unavoidable that it is unthinkable that the power to disregard a law passed in defiance of a constitutional prohibition or a constitutional limitation of legislative authority should not reside with a judge who is sworn pursuant to the Constitution, to support the latter and whose duty is thereby declared to regard it as the supreme law. It appears logically impossible to conceive that the power to refuse to give effect to a legislative act in defiance of a constitutional prohibition is not resident in a body who are made to take oath ${ }^{1}$ either actually or in substance, that they will support the Constitution including its prohibitions or to whom it says that it is and must be the supreme law. ${ }^{2}$

Therefore, there is really no need to point to or rely upon either precedent or usage to establish the proposition. If it were approached anew it would still establish itself, that the judiciary under a written Constitution containing prohibitions which they are sworn to regard as the supreme law, are the possessors of the power to give legal effect to its prohibitions by diregarding laws passed in defiance of them. Any criticism of the exercise of this power is a criticism of the Constitution, and not of those who give effect to it. There are those who thoughtlessly urge that it is a power which should be exercised with wisdom, but this implies that its exercise can, when it seems inexpedient, be avoided; it suggests that it should be used when it seems wise to use it and declined when it seems wise to let it fall into disuse. Such, however, is not the duty of a judge. It is his duty to use the power

1 E. g., N. Y. Const., Art. XIII, s. 1; U. S. Judiaciary Act of 1789, s. 8; U. S. Rev. Stats., s. 712 ; U. S. Judicial Code, s. 257.

2 U. S. Const., Art VI, s. 2. 
when the facts present a case where the power exists; it is the right of each litigant to invoke that power and to insist upon its use; he does not resort to the Court for constitutional indication in its discretion, but to learn from it whether the case is one in which its power exists. If the Court determines that the power exists in respect to the situation presented, it is the right of the individual litigant to secure its exercise. It is, therefore, not a power to be used with so-called wisdom, but to be used whensoever its possessor determines that it ixists under the Constitution in respect to the case made before it. It may and does take intelligence, knowledge and accuracy of perception to determine whether the case presents a violation of a constitutional prohibition, but in such case no amount of wisdom would justify a judge in refusing to declare null and void a legislative act which violates a constitutional prohibition.

It has been claimed that there is a growing tendency in the Courts to condemn as unconstitutional legislation designed to promote social welfare. This proposition should not be conceded, but rather that there is a growing tendency among legislators to disregard constitutional prohibitions in enacting legislation to please certain, and perhaps a majority or powerful minority, of their constituents. Let us consider the effect of giving legislators free scope.

The Constitution prohibits the quartering of soldiers in time of peace upon civilians. This was an evil to which individuals had been frequently subjected by arbitrary authority against which they could make no headway, and which was yet unjust; its excuse was undoubtedly the social welfare, but it bore unevenly and unjustly upon individuals. If a Legislature should by unanimous action determine, in order to avoid levying a direct State tax, to quarter one soldier upon every fourth civilian in the State and the act should be declared unconstitutional by the judiciary, this would not illustrate a growing tendency upon the part of the latter, but of the Legislature; it would be a growing tendency on its part to avoid distributing public burdens equitably: So, also, when, in the guise of improving the social welfare, it attempts to fix upon an individual a burden for the benefit of another individual, and the quartering of the latter upon the former is likewise forbidden by a constitutional prohibition, it is the legislative tendency to act unjustly or at least unconstitutionally that is emphasized by a judicial exercise of the power and the duty to de- 
clare such legislation unconstitutional. Any one who is cognizant of the long line of abuses of the past, by which supreme injustice was done, not only to individuals, but to society through the arbitrary oppression of its individual members, will readily recognize what a great boon to society the concept of protection to the individual through process of law was. And when this concept was embodied in a written Constitution or guaranty, its continued observance marked a substantial advance in the peace and prosperity of the individuals making up the community ; they were free from the mere aggressions of arbitrary power. When the good of the community is urged in favor of violating a constitutional guaranty, the way to achieve the good (if good it is) is to abrogate the guaranty in constitutional ways, instead of abusing the judiciary for upholding the Constitution, as it is sworn to do in a solemn compact with the people, signalized by an oath, before being permitted to assume the office. ${ }^{3}$

In respect to causes of discontent, $I$ have for several years been observing and gathering data from several sources. Obviously there is widespread discontent in respect to our judicial sytsem. and the manner in which justice is administered. These causes are numerous, and they operate differently upon different classes and in different parts of the community for different reasons; although they co-operate to produce the sum total of discontent.

THE INJUNCTION.

The first, and until recently the most numerous class to be discontented, were those who claimed that the power of injunction is abused. This is, however, now overshadowed by the complaint against the so-called annulment of legislative acts.

When men propose to commit violence in order to accomplish their purposes, and to do an injury to coerce an opponent into doing their will; and their opponent invokes the judicial power to protect him against their threatened activity, and the judge appealed to finds that the law does in theory and should in fact protect the postulant, the defeated and their sympathizers denounce the judge instead of the law. They consider themselves the victims of injustice, become discontented with the judiciary, because. it enforces the law against threatening violence and doing injury. This was recently the most widespread cause for criticism of the

${ }^{3}$ E. g., N. Y. Const., Art. XIII, s. 1; U. S. Judiciary Act 1789, s. 8; U. S. Rev. Stats., s. 712; U. S. Judiçial Code, s. 257. 
judiciary. It finds its excuse in the belief that there should exist a privilege of violence, when utilized to improve the condition of a large and united class in the community. Our law hitherto has not recognized such a privilege, and our judicial remedies hitherto have been sufficient to prevent its exercise. The cases in which this power has been used, have been relatively few, but very conspicuous.

As the aggressors have in many instances themselves been the victims of selfish and oppressive treatment, the discontent at their receiving a judicial set-back in the commission of an unlawful act, has been directed at the judiciary, which has done its lawful duty; and many sympathizers have shared the discontent, largely because of the identity of the litigants, rather than the merits of their respective sides of the particular controversy.

Whether violence promotes social welfare, is perhaps a subject which statesmen may properly discuss, but the time has not arrived yet when judges may properly refuse to use the power committed to them to prevent violence and injury to those possessed of rights, in order that the social welfare of the wrongdoers may be promoted.

This cause of discontent I would catalogue as the determination that the law should recognize the right of the discontented to injure those against whom their activities are directed. As I can see no merit in the proposition so stated, I have no recommendation for its remedy, except to suggest that the power of judges to punish for contempt is one which should not be unlimited nor unregulated; that it may be arbitrarily exercised, and that it might well be curtailed and carefully regulated by law, not in the interest of unrestricted violence, but for the protection of a reasonable liberty.

\section{"SOCraL" LEGISLATION.}

The most widely spread discontent arises from the inauguration of legislative measures designed to do good to the community, through doing good to one of its classes, without regard to the injury which may be done to another. This class of remedies has the merit of legislative sanction, which mere acts of violence have not. But this class is peculiarly like the quartering of soldiers on individuals for the good of the community. Its defect lies in the fact that it selects an individual for the victim. That society can do for society what it will is not denied by the Judi- 
ciary nor by the Constitution, provided that society furnishes the means, and does not saddle the individual with the duty while society gets the benefit. Society may take private property for public benefit, but society must, under the Constitution, recompense the man from whom it is taken. It is a highly civilized community in which society can be induced not to sacrifice the weakest individual by making him yield to the arbitrary demands of society. Society has developed through long ages in which arbitrary power did not hesitate at violence or injustice. And the individual man, not possessed of power, was the distressed victim not of society, but of arbitrary power. Fortunately for us and our country hitherto there were curbs upon arbitrary power, which the individual might invoke through the Judiciary to prevent his own sacrifice to its demands. And this was for the good, and not to the detriment of society; for society was made up of individual men, all similarly protected, without discrimination under the Constitutions.

Society was always capable of improvement, however, by taking thought, and the thoughtful have resorted to the Legislatures and the Legislatures have been won over, and have enacted the demands of those who have taken thought, only to find the demands thwarted in the Courts by the determination of unconstitutionality, and this has awakened the present clamor against the Courts, the Constitution and the Judiciary; a clamor more widespread than that which arises from the so-called abuse of the injunction; a clamor which includes social workers and others who would not advocate unrestrained violence, but who do nevertheless advocate unrestrained legislation. But the very fact that legislation is declared in contravention of constitutional principles which it has taken ages to work out for the benefit of the peace and happiness of society should cause some sober reflection whether society has not made a mistake in attempting legislation for the benefit of a class in society, which appears to the Judiciary at least to override philosophic principles that have been the outgrowth of hard-bought experience under the opposite principles. Legislatures and social welfare workers should heed the warning voices of the past, as much as judges who are sworn to do it. It appeared to Herod a certain way to get rid of the prospective King of the Jews; if he should kill all infants under two years of age in Bethlehem and all the coasts thereof ; but not-

4 Matt. II., 16. 
withstanding all of the unjustified slaughter he failed of his purpose. The most obvious way of accomplishing a given purpose is not always the best. And when it becomes apparent that a proposed measure runs counter to a safeguard established after ages of experience for the good of the community, it is wise to stop and ask whether the end might not be attained while preserving the principle.

The social worker, and the legislator who aids his good intent, have, it seems to me, lost sight of this fact. The gypsy moth is said to have been introduced into New England to do unmeasured destruction, through the accidental breaking of a net in which it was confined for experimental purposes by an investigating biologist. The Constitution gives the Judiciary the power, and requires its exercise, to prevent the spread of legislative gypsy moths.

It is the Legislature which determines whether a measure is for the good of society, but the Judiciary still holds the screen to prevent the escape of the gypsy moth. The Judiciary does not inquire whether it is for the good of society, but whether it is a gypsy moth. Even the police power, in this view of the Constitution, is confined by the constitutional screen, and the Legisiature, which is prohibited to trandscend the Constitution, should be justly governed by its bounds and caught within its meshes. It is not for the Judiciary to say whether the Constitution ouglut to be, for it is; they did not make it, but they each swore to uphold it, before they were permitted to assume office, and the Legislature is not, nor are a clamorous and racous-voiced few empowered to release them from their oath. New York is typical of the most extreme conflict between the Legislature, enacting measures at the behest of one class to accomplish a fancied good, and the Courts doing what they conceive to be their sworn duty to uphold the Constitution against legislative attacks. The Legislature has unsuccessfully attempted to prohibit tht making of cigars in tenement houses, ${ }^{5}$ to prohibit the sale of railroad tickets by any except common carriers, ${ }^{6}$ to prohibit the manufacture or sale of oleomargerine, ${ }^{7}$ to prohibit women from working in factories between 9 p. m. and $6^{8}$ a. m., to impose upon one man the

"Matter of Jacobs, 98 N. Y., 98.

- People ex rel. Tyroler v. Warden, 157 N. Y., 116.

7 People v. Marx, 99 N. Y., 377.

s People v. Williams, 189 N. Y., 131. 
duty of paying a pension to another, ${ }^{9}$ to restrict the business of soliciting insurance to those engaged in limited lines of other business, ${ }^{10}$ and to prevent a man from acting as agent in the sale of real property unless his authority is committed to writing. ${ }^{11}$

Each of these legislative attempts has been thwarted by a Judiciary sworn to uphold the Constitution and each has been a gypsy moth capable, according to the Judiciary, of working the destruction of the peace and happiness of the community by taking away from an individual something which was rightfully his. When the Legislature in the interest of a class, restricts the previously lawful activities of another class, it injures the class restricted, and while it may benefit certain of its constituents, it may injure the true peace of society. Constitutions, with their prohibitions of certain legislative activity, exist for the well-being of the entire community as a whole; they have been worked out through hard-bought experiences, and have been established by the regularly authorized representatives of the whole peop'e. The prohibition of cigar making in tenement houses, deprives a large and industrious part of the community of a reasonable opportunity to make a livelihood; it restricts the making of cigars to those who can afford to pay rent for a separate factory; it discourages the individual worker in the interest of those who have the capital to hire a place for many workers; it thwarts independence; it makes an arbitrary rule; the Legislature might establish uniform regulations to keep cigar factories of all sorts clean and healthy, but it could not constitutionally prevent a man from making cigars in a clean and healthy place, merely because some part of the same building was used for human habitation. I might take up each of the unsuccessful attempts in turn and explain how the Legislature might have accomplished its design so far as reasonable without violating a constitutional principle, but it would not be profitable. One can readily see that a slight extension of the legislative assertion of power would greatly curtail the reasonable activities of a large part of the community. If it is constitutional to prohibit the manufacture of cigars in certain houses, it might be permissible to confine the manufacture to certain places, or to certain individuals; a restriction of the hours of labor of bakers or of women might prevent bakers or women

9 Ives w. South Buffalo Ry. Co., 201 N. Y., 271.

${ }^{10}$ Hauser v. North British, etc., Co., 206 N. Y., 455.

11 Fisher Co. v. Woods, 187 N. Y., 90. 
from making a living if carried farther; the admission of the Legislature's power to compel one man to support another in case of physical misfortune might authorize the Legislature to take away one man's property and give it to those without misfortune; if soliciting insurance be confined to those in the real estate business, it might be confined to men with one arm or with red hair, or it might be confined to those specifically named as the recipients of legislative favor. And so, if we admit the Legislature's unrestricted power, we leave it altogether free to destroy all freedom of action. If it can, without judicial interference take property without due process of law, it can also institute cruel and unusual punishments; it can declare that the office of assemblyman shall continue through life and be heriditary; it can abolish all elections; it can repeal the Constitution. Now, I can conceive and advance reasons why each of the unconstitutional laws cited might have been held within the legislative power under the Constitution. I could cite two cases, from different States, ${ }^{12}$ in which it has been said by way of argument, in one that the Legislature might constitutionally prohibit the practice of medicine by men with red hair and in another that such action would transcend legislative power. This is merely an indication of the different way in which different minds look at the same problem, the one apparently considering that there is obviously such a lack of relation between red hair and medical skill, that the legislative action is an arbitrary discrimination between the rights of men with red hair and those with white, black, yellow or no hair, the other contending that the Legislature has an unrestricted right to determine the relation between the color of red hair and medical capacity. While we may disagree with the reasoning in a particular case, that is small ground for overthrowing our institutions. Many of us think it reprehensible to nullify a legislative act, which imposes on an employer, the necessity of supporting all of his disabled workmen, while we might view with alarm legislation which imposed upon a colonel the duty of supporting all of his regiment injured in battle. Yet.the principles of the two cases are fundamentally the same, for a single employer can not as easily add to the cost of his product to make up the cost of the keep of his injured employees, as a colonel of a regiment could levy upon the surrounding country to keep up his pensions.

${ }^{12}$ Cf. Ex Parte Spinney, 10 Nev., 323, per Beatty, J., and dissenting opinion of Morse, J., People v. Phippin, 70 Mich., 6. 
THE JUDICIARY IS NOT AT FAULT.

There are then two great fundamental causes for the present widespread dissatisfaction with the Judiciary; each the result of a determination on the part of a large element of the community, to wreak its individual will on others in the community, regardless of its effect upon those others; and the Judiciary is blamed because it grants to those others the protection, which in the opinion of the Judiciary the Constitution was designed to afford. The disapproval is the disapproval of disappointment; it is easier to abuse a judge than to change a Constitution. But the thing which stands in the way is the latter not the former and the former should not be blamed for obeying his oath.

Insofar as I have considered the two subjects which I have discussed the evils and the weaknesses are not to any great extent in the Judiciary; it is the strength of the latter which has given rise to the discussion; it is the desire to weaken it, so that it will bend the everlastng principles of justice to the immediate demands of a clamorous multitude. As I see it, the evil is in the demand, and not in the Judiciary. The demand contemplates that a united will of less than the whole people shall acomplish its purpose in defiance instead of in harmony with fundamental principles. If fundamental principles are to be changed, it should be done through the Constitution and not through the Judiciary; the Constitution is the word of the master, the Judiciary its servants. And the Constitution is itself not master. The people is still master, but not a minority of the people. There are two remedies, neither, however, applicable to the Judiciary, viz.: to change the Constitution to embody the will of the people, but not of a minority, or to direct the will of the people to accomplish desired results in harmony with the Constitution. While the latter can be done, the former should not be done; the resort to the former sacrifices too much of experience in the interest of doubtful experiment. I do not see any one of the purposes, whose particular method has been disapproved by the Judiciary which might not be constitutionally and wisely accomplished through properly conceived constructive, as distinguished from destructive legislation; legislation which would take into due consideration the just interests of all, instead of the selfish interests of a portion. Toleration is the solution of many evils, which intoleration perpetuates. Rather take constitutionalists into council, and devise a consti- 
tutional and just method of accomplishing desired reforms, instead of denouncing their prejudices and precautions as matters to be disregarded and overriden to offer the easiest way to a desired or uncertain goal. To use but one illustration, the taxing power can be properly and constitutionally invoked to pay civil pensions to the injured soldiers of industry instead of quartering them upon an employer, who may himself be wholly unable to bear the burden of having his property taken without his fault to answer for the misfortunes of those whom he has adequately compensated for the service rendered during the term of their employment. It is not the pensioning of disabled employers which the Judiciary has found unconstitutional, but the despoiling of the innocent employer in order to secure the fund for "social justice." I confess that I might find the institution of a system of pensioning disabled employees in dangerous employments at the expense of their innocent employers, constitutional, as a lawful condition imposed upon particular enterprises because they do threaten the peace of the community by their very danger, and the condition might be constitutionally made the price of the license to engage. But I cannot condemn a judge for finding otherwise, on the theory that dangerous employments do not fall outside of the general category, and that it is a fundamental prin.ciple in our justice that a man's property shall not be taken for public use without just compensation, and that it cannot be taken for private use without his wrongful act. If we let down this bar and suffer it to be taken at the will of the Legislature, then we will put all men in the community at the mercy of the Legislature and abolish the established principles of the Constitution; this, the people may do, if they choose, but the Judiciary cannot do it until they have the people's mandate constitutionally expressed and the Legislative edict is not the people's mandate, so long as the Constitution prohibits the legislative act, and estahlishes the limit of legislative power Those who advocate the abolition of constitutional restrictions upon legislative power. merely do so, because the Legislature attempts to work their will. If the Legislature should defy their will, they would not be so ready to desert the Constitution or its principles established through years of violence, injustice and painful experience of contrary methods. 


\section{WORKINGMEN'S COMPENSATION.}

The weakness and evil, then, is not in the Courts, but in methods of advocacy and leggislative fiat in disregard of individual claims to fair consideraton. This is no place to discuss the economic dangers of taking one man's property and giving. it to an. other, illustrated in the case of so-called workingmen's compensation wrought through merely giving the working man a right to prosecute a law suit against his employer, for their joint misfortune. But it may not be amiss to point out that a scheme of workingmen's "compensation" which merely creates a right of action, where none existed, and abolishes a defense hitherto recognized as fundamentally just, does not in fact give the injured workingman the prompt relief which he needs, and it secures no relief against an insolvent employer, or one who becomes insolvent during the term of so-called compensation; it does not eliminate the ambulance choser nor the accident lawyer, it does not disgorge the Court calendars, nor lessen the actual chances of waste, delay and expense; it still permits a 50\% lawyers' fee, and it limits the size of verdicts, so that they do not include damages for this waste, delay and expense; while, on the other hand it falsely assumes that all employers of labor are capitalists and can readily stand the shock of the sudden increase of expense caused by an unexpected, unavoidable and extensive casualty; it falsely assumes that the individual employer can distribute the cost of such an accident to his customers by raising the price of his product while in competition with another, whose experience of unavoidable accident has not yet arrived; it falsely assumes that the individual employer can fully protect himself, and the workman at the same time realizes his dream of compensation, by insurance in a company organizèd for profit and whose profit is enhanced by the number of defeated claims. In short, not only does such legislation override the wisely conservative principle of the protection of property to the extent of due process of law, but it fails to give the workman cheap, certain and prompt relief, while it diminishes the amount of recovery below its present reasonable possibilities in case of wrongful act, and tends to hopelessly cripple the small employer, who enjoys credit and not capital; it tends to discourage the rise from the class of employees to employers, because it imposes an obligation which requires capital to meet it; it fixes its eyes upon the larger capitalist 
as an employer and overlooks the man struggling up from obscurity. All of this for the time being the Judiciary has discouraged by a conscientious appeal to constitutional bars. The remedy lies, not in the abandonment of civil pensions for injured employers, but in the fairer distribution of the burden, so that society meets its obligation, such as it is, and does not quarter its soldiers on the struggling individual whose burden is thereby 1endered so overwhelming that both innocent employer and injured employee succumb under it. The fairer distribution of the burden would consist in the equitable exercise of the taxing power, so that trades and employments could be classified according to their hazard, and taxed by license fees graduated according to proper factors, to raise an aggregate fund sufficient to meet the aggregate demand; litigation should be avoided and insuranie. with its element of private profit should be eliminated. The injured employees should receive all of the fund, except the actual expenses of its administration, and there should be no profit in delay and disappointment, as there is in litigation to defeal clanns. Courts, with their expensive and formal procedure, with their law, their lawyers, and their attendants should not have any function in the distribution of the fund; the whole thing should be administrative and not judicial. The fault which is now attributed to the Courts, really lies in inefficient legislation, which does not meet the actual need, but attacks a fundamental principle in our institutions without accomplishing the assumed social justice, even to the part of the community which it assumes to aid.

The recently enacted Workingmen's Compensation Law in New York ${ }^{13}$ still only partially recognizes these principles, but it gives much more heed to them than its unconstitutional predecessor.

The criticism which has bien leveled at the Court of Appeals of New York for its unpopular decision in the so-called Ives case, ${ }^{14}$ under the former workingmen's compensation law, ${ }^{15}$ is not well founded and should be answered and discouraged by those who know enough to do it. Personally I could have found sufficient reason in the facts of this case to reach a different conclusion upon the law, but there is really more protection to the individual, be he rich or poor, and to the happiness of the com-

13 Laws 1913, c. 816, Act Dec. 16, 1913.

${ }_{14}$ Ives v. South Buffalo R. R. Co., 201. N. Y., 271.

15 Laws of N. Y., 1910, c. 674. 
munity, in a Constitution which restrains the injustice of numbers and in a judicial branch which closely scrutinizes arbitrary acts of legislation, than in a complaisant or powerless Judiciary, which passes over in silence a piece of unconstitutional legislative injustice.

THE "WILL OF THE PEOPLE" IS EMBODIED IN CONSTITUTIONS,

We should unmask and denounce the plausible contention that what is demanded is the accomplishment of the will of the people; what is demanded is that our so-called representatives elected to the Legislature shall have unrestricted sway over the fortunes, the lives and the happiness of the people, without interference or effectual criticism from our other elected representatives, the Judiciary. Any such rule will be inevitably fraught with danger. For our Legislatures in the past have not distinguished themselves by any high regard either for constitutional principles, or the rights of individuals. The present universal agitation is founded more upon the widespread exposure of graft, than on any other fact; and successful graft owes its acomplishments, not to a corrupt Judiciary, but in the most instances to corrupt municipal legislatures.

The following extract from the address of Louis Marshall, Esq., to the recent High Court of Impeachment in New York, is pertinent to the present discussion and deserves wide circulation in this connection. He said:

"That would be a sad day in our judicial history when reliance upon the Constitution and the law of the land were to be regarded as technical, or were to be condemned and deemed unworthy. So long as our people may proudly boast that this a Government of laws and not of men, so long will its liberties be preserved and its institutions perpetuated. But whenever the time shall come when the ignorance of the mob, its passions and its prejudices, or when considerations of mere political expediency, may prevail against the word of the organic law, when the timehonored concepts of 'due process of law' and the law of the land shall be treated as mere jests, and become the objects of derision and contempt, when the usurpation by one branch of the Government of the powers which belong to another, may be regarded with equanimity, then the hour of disintegration will be at hand, and it will only require one endowed with the necessary audacity to ride rough-shod over the ruins of the Constitution, and that sys- 
tem of Government which has made of us a people happy, lawabiding and free, will give way to the hysterical caprices of tyranny and despotism.

"We are confident that this tribunal will not shrink from the duty of applying the Constitution, regardless of the outcries of those who, for ulterior reasons, are prepared to strike it down if it stands in the way of the accomplishment of their selfish purposes. It is one of the glories of our Court of Appeals, that it has steadfastly closed its ears to the discordant ravings of those who have from time to time demanded that it do violence to the Constitution and the law, in order that the victims they have sought to immolate might not escape their vengeance. It has never been terrorized or coerced by threats or cajoled by flattery or influenced by ridicule, or by the fear of unpopularity, into doing an act of positive injustice, and the sneer which regards the taking of shelter, under the Constitution, as a technicality, has never led it to withdraw its protection from him who sought it."

THE SELECTION OF JUDGES, AND THE PERSONNEL OF THE JUDICIARY.

There is a third cause of the discontent with our Judiciary, which is not usually recognized, and that is the selection of judges for purely partisan reasons, in disregard of eminent fitness for the position. The knowledge that judicial position is the gift of an individual, whether President or boss, for the benefit of a party organization or as a reward for partisan service deprives the incumbent of respect in the position, and casts suspicion upon the disinterestedness of his decisions. A man who is a partisan of the Bench is not apt to be impartial when on it; and a man who has earned his selection by subserviency is not apt to distinguish his occupancy by independence. One may entertain his individual opinions, and they may not be correct; but when he inaugurates a widespread inquiry and finds those opinions echoed by numerous others, not likely to be influenced by the same injtances or causes, he has substantial reason to believe that his views are well founded. Mr. Everett V. Abbot ${ }^{16}$ and myself about three years ago made serious effort to sicure a widespread expression of views upon the Judiciary; we directed inquiries to every State; and we got numerous replies from a widely extended

${ }^{10}$ Author of $J_{1 i s t i c e}$ and the Modern Law, Haughton, Mifflin Co., Boston, 1913. 
field. We then tabulatedi and analyzed those replies, with a result which we published in the American Law Review for July and sugust, 1911. ${ }^{17}$ The questions sought to learn how the Judiciary was regarded in all of the communities reached, both by lawyers and laymen. The answers received were varied; they showed that in some commonwealths and communities they were regarded with esteem, confidence and admiration; in others, some of the members were severely criticised. In its ultimate analysis the criticism might be summarized, in the two words, faulty personnel. In not one of these replies did we hear of any abuse of the power of the injunction, or of any usurpation of the power to retard social welfare by declaring legislative acts unconstitutional. These reasons loom large now because they have been agitated targely to serve partisan purposes, and are issues upon which ambitious individuals may themselves ride into power. But what we heard from men of judgment and with the power of observation, but with no axes to grind and no propaganda to advance, was a reflection upon the kind of men that are in some instances elected to the Bench-men who for on reason and another related to their personal qualifications, were either deemed unfit, or who, at least, did not distinguish the office. The personal unfitness, though it required a long catalogue to specify its peculiar character in individual cases, obviously had a single result, it destroyed respect for the particular incumbent's administration of his office. .This unfitness of individual judges reported by quiet observers, not distinguished as malcontents showed that in a large measure those who have the privilege of selecting judges are doing their work poorly. In some cases it was a President of the United States, who in those cases, according to our informants, was considered to have chosen members of his own party, as a party reward, but without regard to distinguished fitness; in such cases the appointing power was known and could be indicated; in other cases, it was clearly indicated that the incumbent was elected by popular vote. The impression was gained that there was little or no complaint where the appointing power was lodged in the Governor of a State. It seemed that the failure readily fell into two categories, selections by the Federal appointing power in communities where his party was not dominant, and members of an elected Judiciary. But in no case was the discon-

${ }_{17}$ The Judiciary and the Administration of the Law, by Everett V. Abbot and Charles A. Boston. 
tent with the Judiciary, it was with the individuals; and in no case was it caused by their attitude toward injunctions or "social welfare" legislation. In every instance it was the criticism of the personal short-comings of an individual; and in every case, it was either lack of professional attainments or personal qualifications. In no case was there any criticism which could be remedied by the recall of judicial decisions; nor was it intimated that the recall of individual judges would lead to the selection of better equipped successors.

THE TRUE REMEDY.

There is no cure for lack of professional attainments in candidates for the Bench, except to educate the people to demand them. Until the people demand them, there can be no certainty that President or boss will insist upon them, or make fitness or professional ability a ground of selection. Before countenancing the nostrums of recalling judges or judicial decisions, $\dot{I}$ would urge a propaganda that instead of judges who will administer the "people's will," the people select judges whose professional ability and personal equipment distinguish them as eminently fitted for the judicial office.

The short-comings which were reported to us, insofar as they did not lie in lack of ability, lay in a lax appreciation of professional ethics. There is just as much need of canons of professional ethics for judges, as for lawyers. The American Bar Association has failed or refused to perceive this, though it has been repeatedly brought to its attention. The Pennsylvania Bar Association has recognized it and has adopted canons of judicial ethics. When judges know, and people know, that they must measure up to certain simple and well-defined practical standards, there will be fewer short-comings to chronicle, and greater confidence in the Judiciary as an institution, the result of greater honor and respect to its members. We all can appreciate the uniform confidence in the absolute probity and utter dignity and impartiality with which the Chief Justice in New York recently presided over its High Court of Impeachment. Not a shadow of question fell upon his administration of his office, and every one looked to the force of his character as a bulwark in influencing the Court, composed in part of elected legislators, to reach a proper judicial and impartial determination.

What would we ever hear of the recall of judges or decisions, if every judge everywhere were as conspicuous an example to in- 
spire confidence and admiration. Would not the whole movement completely collapse, if the people were made to know and feel that their judges, like their priests, their ministers and their chosen family physicians, were paragons of professional ability and personal integrity?

Whatever may be the rallying cry, the fundamental cause, is not with the judicial institution, but with the bosses. Whoever the boss may be, or whatever guise he may take, he is at fault in choosing men for judicial position, who so far fail to command respect, that anyone can doubt their purity of purpose. When we succeeded in implanting in the average man, the perception that the occupants of judicial positions are men in every way worthy of the position, then this agitation will cease, though it may spend itself earlier. On the other hand, if the average man is impressed that his judge is one whom he can not trust, no recall, whether of judge or decision, will satisfy him. And to beget this confidence the judges must deserve it. It is not the will of the people as it may be understood by the man with his ear to the ground, but honesty, ability, industry and impartiality, which should dictate the course of the judge. And it is honesty, ability, industry and impartiality which will steady the judicial department and hold it free from the influences that now seek to make it the weather vane of popular fancy.

It is not semi-monastic solitude, traditional veneration of the Constitution, or a natural instinct to preserve property rights, which has weakened the Judiciary, but the fact that the people were not individually impressed with the wonderful integrity, the amazing ability, the great industry and the utter impartiality of the Bench. There are communities in which they are so impressed; and in any community in which they are so impressed, any attack upon the Judiciary or its powers is doomed to sure failure.

The faults of delay and complex procedure are not the faults of the Judiciary, but of the Legislature. It is to be hoped that these will be remedied by the agencies which are now at work in many parts of the United States to simplify procedure and promote remedial justice.

The essense of this individual opinion of mine is:

1. That the power of the Judiciary to declare laws unconstitutional is beneficial and is not open to just criticism. 
2. That there is a growing tendency in Legislatures to pass unconstitutional legislation which should not be encouraged.

3. That all legislation necessary or desirable for social welfare may be passed, without violating any fundamental provision of the Constitution.

4. That the causes of the present discontent are:

(a.) The desire of certain persons to enjoy the unrestricted right to do violence, without the exercise of the restraining power of a Court to protect the victim;

(b.) The desire to benefit one class at the expense of another but innocent class, and without distributing the burden where it rightfully belongs and may be constitutionally placed;

(c.) The too frequent lack in members of the Judiciary of those qualities of ability and integrity which command respect for their judicial decisions.

5. Of these causes for discontent, the first contention is inherently unjust and cannot by right thinking men be conceded;

The second object can be and should be constitutionally achieved without assailing or curtailing the powers of the Judiciary ;

The third cause can only be removed by educating the people to demand the best of material in the judicial office;

The faculty and expensive procedure where it exists is not chargeable to the Judiciary, but to the Legislature which is empowered to correct it.

New York City.

Charles A. Boston. 